\title{
True cicadas (Cicadidae) as prey for the birds of the Western Palearctic: a review
}

\author{
Pere Pons ${ }^{*}(0$
}

\begin{abstract}
Background: True cicadas (Cicadidae) are large and temporarily abundant insects. Their availability may produce demographic and behavioural effects on bird populations, as happens with forest avifauna feeding on periodical cicadas in North America. In Europe, the Near East and North Africa, knowledge of cicada predation by birds is sparse.

Methods: To help fill this gap, I consulted Cramp's Birds of the Western Palearctic, conducted a search of online databases and used search engines to generate a database of Western Palearctic birds known to eat cicadas.

Results: A total of 105 species (16\% of those occurring in the region) belonging to 13 orders, and comprising 20 of the 33 passerine families, were found to consume cicadas. I estimated that 69 of these bird species are known to consume cicadas within the limits of the Western Palearctic. Many terrestrial birds predate on cicadas, preferably on adults. Avian predators include cuckoos, owls, bee-eaters, woodpeckers, falcons, reed-warblers, larks, crows and jays, buntings, shrikes, pipits and wagtails, flycatchers and chats, tits, sparrows, leaf-warblers, starlings, warblers and thrushes, but also terns and gulls. Nymphs are consumed by some passerines, owls and herons. Cicadas can make up as much as $70 \%$ of food items delivered to nestlings. Analysis of stomach contents and neck collar samples are the most common methods used in diet studies.

Conclusions: Available knowledge is biased towards species that have been more intensively studied, and often lack proper quantification of prey items. More studies about the relative importance of cicadas as prey for birds in the Western Palearctic are needed. I suggest using non-invasive studies based on pellets and droppings and prioritizing declining bird species.
\end{abstract}

Keywords: Bird species, Cicadidae, Cramp's handbook, Diet studies, Predator-prey relationships

\section{Background}

Cicadas (Hemiptera: Cicadoidea) are a conspicuous group of insects, mostly occurring in warm and temperate biomes. Adults emerge after several years of juvenile life belowground to live a few days strictly as sap suckers in vegetation (Boulard and Mondon 1995). Many species emerge massively and can therefore be important elements in the food webs of forests and shrublands, at least for a few months every year (or every 13 to 17 years in North American periodical cicadas). Cicadas are also

\footnotetext{
*Correspondence: pere.pons@udg.edu
}

Departament de Ciències Ambientals, Universitat de Girona,

17003 Girona, Catalonia, Spain main contributors to the daytime soundscape of natural areas, with their sound intensity increasing as the day and the season progress, becoming dominant over bird songs (Farina et al. 2011). Cicadas started singing in the Cretaceous (Senter 2008), using song mainly for courtship. Song can be used by insectivorous animals, like birds (Lovette and Fitzpatrick 2016), to detect singing males.

Some cicada species can reach high densities, being important prey, when available, for many invertebrates and vertebrates (Boulard and Mondon 1995). Birds have been documented feeding on cicadas in most biogeographical realms: Palearctic (Patterson et al. 1991), Nearctic (Karban 1982), Afrotropic (Dean 1993), Neotropic (Sazima 2009), Australasia (Tokue and Ford 2007) 
and Indo-Malaya (Torno 2005). Papers often report anecdotal observations, while others are studies on the diet of specific bird species. However, detailed studies on trophic relationships between cicadas and birds, focusing on their ecological and evolutionary implications, have been conducted with North American Magicicada spp. These periodical cicadas emerge synchronically in huge numbers every 13 or 17 years depending on the species. In the hardwood forests of the eastern United States the resource pulses available at such long lapses have demographic effects on avian predators ( 15 species were found to be significantly affected), mostly during or immediately after emergences (Koenig and Liebhold 2005). This results in lower potential predation pressure during the subsequent emergence, also shaping the evolution of cicada life history (Koenig and Liebhold 2013).

Insects can satisfy most of the nutritional needs of birds, except carbohydrates and calcium, and are rich in essential amino acids (Capinera 2010). Birds, including those of plant-based food regimes, often feed insects to their chicks, because rapidly growing animals need a diet rich in protein and fat (Capinera 2010). Cicadas are large insects with the largest species reaching $7 \mathrm{~cm}$ in body size, although some taxa are as small as $1 \mathrm{~cm}$ (Encyclopedia of Life 2019). They are therefore consumed by relatively large birds, including raptors, herons, gulls, cuckoos, bee-eaters and rollers (Sazima 2009), but some small passerines are also known to eat cicadas (Koenig and Liebhold 2005). Unlike studies on North American periodical cicadas, knowledge of the bird predation of annual cicadas in the Western Palearctic (WP) appears to be dispersed and incomplete.

True cicadas belong to the family Cicadidae, comprising three subfamilies supported by recent morphological and molecular analyses: Cicadinae, Cicadettinae and Tibicininae (Marshall et al. 2018). There is no comprehensive updated list of cicada species in the WP, because of insufficient studies in North Africa and the Middle East. In Europe, there are currently 16 genera and 75 species known to science, with the small-sized Cicadettinae, comprising 53 species, being the most diverse (Gogala 2019). Species number will certainly increase due to developments in bioacoustics and molecular phylogeny as well as a result of new studies in less-prospected regions. Cicadas are particularly adapted to warm climates (Sanborn et al. 2011), so a latitudinal gradient of increasing species number goes from north to south. The Aegean Sea islands, the Balkans and Southern Iberia constitute hotspots of cicada diversity (Puissant and Sueur 2010; Simoes et al. 2013), whereas the British Isles hold a single species. Nymph underground life can last up to 7 years in the WP (Boulard and Mondon 1995), since there are no periodical cicadas with long-term synchronic emergence. In contrast, adults live for one or 2 weeks. The cicada above-ground period mostly embraces June to September, includes peaks of abundance of different phenology among species, with high densities in suitable local habitats (Pons 2015).

The aims of this study were to collect and synthesize current knowledge about the occurrence of cicadas in bird diets. The working hypothesis was that cicadas can be predated by many bird species in the WP. Specifically, the detailed objectives were to evaluate the amount and quality of information, to know which bird orders, families and species are known to consume cicadas, what methods have been commonly used, and what the contribution of cicadas to the food regimes of WP avifauna is.

\section{Methods}

\section{Information search and filtering}

The main source of information for this study was Cramp's Birds of the Western Palearctic on CD-Rom (Cramp et al. 1998), hereafter referred to as CBWP. This is a searchable resource that includes a nine-volume handbook plus a concise two-volume edition, covering 960 bird species. I first searched for the terms "cicadas", "Cicadidae" and "Cicadoidea" in the food section of the CBWP. This search provided detailed information on food eaten by all the species that included the terms, which have been highlighted. Texts were copied into a word file for subsequent analyses. I then updated the bird taxonomic information using a comprehensive checklist of the birds of the world (HBW and BirdLife International 2018). Five bird species included in the search results (Azure-winged Magpie Cyanopica cyanus, Great Grey Shrike Lanius excubitor, Yellow Wagtail Motacilla flava, Bonelli's Warbler Phylloscopus bonelli and Orphean Warbler Sylvia hortensis) had been split into new species since the publication of the corresponding volume of the CBWP. I decided which of the resulting species should be kept, using the geographical information provided in the text where the term "cicada" appeared.

I also searched for the combination of terms "cicada AND bird" in the Article Title, Abstract and Keywords of the Scopus database (finding 60 references) and in Zoological Records (finding 97 references). I checked these papers to retain only the ones referring to cicada as a food source for bird species occurring in the Western Palearctic. I finally looked for additional bird species in web pages using Google search and pictures using Google images. I applied the same filters as above. For the sake of simplicity, the whole set of sources are hereafter referred to as "diet studies".

In some diet studies leafhoppers (Cicadellidae) were incorrectly referred to as "cicadas" (e.g. Itamies et al. 1996). The CBWP text, as well as the rest of sources used, 
was checked to exclude those bird species for which cicadas had been cited in their diet but which probably corresponded to Cicadellidae. Internet references to cicadas in diet were also excluded when the accompanying images shown were incorrectly or doubtfully determined. Several citations, but only four species (Grey Partridge Perdix perdix, Lesser Kestrel Falco naumanni, Yellowbrowed Warbler Phylloscopus inornatus and Eurasian Blue Tit Cyanistes caeruleus), were eliminated through this process.

\section{The database}

I then generated a database of cicada-eating birds occurring in the Western Palearctic (Additional file 1: Appendix 1). For every species, four types of variables were considered: species-specific, information source, geography and cicada consumption. The five species-specific variables included Order, Family, Common and Scientific names and IUCN Red List category (2018 edition). Information sources were divided into CBWP and other sources ( $0-1$ variables). Geography referred to the occurrence of cicadas in bird diets in large regions $(0-1$ variables): World, Palearctic and Western Palearctic (WP), and to the names of the countries cited by the studies, when available. If no information was found, World was the only positive variable. Cicada consumption referred to: (a) the methods used in diet studies (0-1 variables), analysing neck collar samples, stomach contents, pellets and regurgitations, droppings, visual data (including photography and video recording), and nest remains; (b) the maximum number of cicadas found in studies (usually absolute number of cicada preys, maximum number of cicadas relative to the sample, or percentage of the total number of preys), and (c) the occurrence of nymphs in diet. The species identity of consumed cicadas was also of interest, but fine taxonomic identification was seldom performed by the consulted studies.

A second database included the number of species of every bird family and order occurring in WP, giving a total of 651 species. This was based on the information found in the CBWP but excluded vagrant, accidental and introduced species in the WP. Taxonomy was updated using data from HBW and BirdLife International (2018) as before. The number of species eating cicadas, and the percentage of species in each taxon known to consume Cicadidae, were then computed (Table 1).

\section{Results}

A total of 106 Western Palearctic (WP) breeding bird species were found to eat cicadas. This represents $16 \%$ of species occurring in the WP, with vagrant, accidental and introduced species excluded. The search in the CBWP provided 95 species, once the filters explained under Methods were applied. The CBWP mostly cited studies conducted from the 1920 s to the 1980 s. The rest of the search provided 27 species, including 11 not found in the previous search, and also more recent studies or data. For 67 bird species, location of the study site was available, but for 39 it was not, since old original references could not be found. From information in the CBWP, it was clear that 21 of these species ate cicadas within the limits of the WP. For the other 18 species, I estimated that 10 of them could also consume cicadas in the WP, applying the 58\% rate of WP cicada consumption of the 67 species with known study location (Additional file 1: Appendix 1). In total, around 70 bird species were estimated to consume cicadas within the limits of the WP and 27 in the Eastern Palearctic only (Fig. 1). There were no globally threatened birds known to consume cicadas, although three currently near-threatened species were found: the Northern Lapwing (Vanellus vanellus), the Red-footed Falcon (Falco vespertinus), and the Meadow Pipit (Anthus pratensis) (Additional file 1: Appendix 1). Diet studies were conducted in at least 13 countries of the WP, especially in southern Europe and the Middle East.

Thirteen of the 25 bird orders occurring in the WP were found to consume cicadas (Table 1). Passerines had the largest number of species (73) known to prey on cicadas. All other orders had six or less represented species, with Charadriiformes, Pelecaniformes and Coraciiformes comprising the top three (Fig. 2a). Regarding the proportion of species in each order, Bucerotiformes, Cuculiformes, Coraciiformes, Piciformes, Passeriformes, Falconiformes and Pelecaniformes contained more than $20 \%$ of species known to eat cicadas.

Twenty of the 33 passerine families occurring in the WP were found to consume cicadas. Motacillidae had the highest number of species with cicadas in diet (and also the highest percentage if families with only one species in the WP are excluded). Paridae, Corvidae, Passeridae, Phylloscopidae and Sylvidae were also well-represented both in terms of percentage $(>40 \%)$ and number of species (Fig. 2b). It is interesting to note that five tern species were found to eat cicadas (Table 1, Laridae), at least one of them within the WP (Ukraine), and also the Mediterranean Gull (Larus melanocephalus) in Greece (Goutner 1994).

Description of the methods used in diet studies was available for $52 \%$ of species found to consume cicadas. Analysis of stomach contents and neck collars were the most common methods employed in the references cited in the CBWP. However, for the rest of studies and in internet results, observation/photography, and the analysis of pellets and of droppings were the most common (Fig. 3). 
Table 1 Number of bird species per family in the Western Paleartic (WP, excluding vagrant, accidental and introduced species), number known to eat cicadas, and percentage of species eating cicadas in relation to the overall number

\begin{tabular}{|c|c|c|c|c|c|c|c|c|c|}
\hline \multirow[t]{2}{*}{ Order } & \multirow[t]{2}{*}{ Family } & \multicolumn{2}{|c|}{$\begin{array}{l}\text { Number } \\
\text { of species }\end{array}$} & \multirow[t]{2}{*}{$\begin{array}{l}\% \text { of species } \\
\text { eating cicadas }\end{array}$} & \multirow[t]{2}{*}{ Order } & \multirow[t]{2}{*}{ Family } & \multicolumn{2}{|c|}{ Number of species } & \multirow[t]{2}{*}{$\begin{array}{l}\% \text { of species } \\
\text { eating cicadas }\end{array}$} \\
\hline & & In WP & $\begin{array}{l}\text { Eating } \\
\text { cicadas }\end{array}$ & & & & In WP & Eating cicadas & \\
\hline Struthioniformes & Struthionidae & 1 & 0 & 0 & Coliiformes & Coliidae & 1 & 0 & 0 \\
\hline \multirow[t]{2}{*}{ Galliformes } & Phasianidae & 19 & 1 & 5 & Bucerotiformes & Upupidae & 1 & 1 & 100 \\
\hline & Numididae & 1 & 0 & 0 & Coraciiformes & Meropidae & 3 & 2 & 67 \\
\hline Anseriformes & Anatidae & 45 & 0 & 0 & & Coraciidae & 2 & 2 & 100 \\
\hline Podicipediformes & Podicipedidae & 5 & 0 & 0 & & Alcedinidae & 4 & 0 & 0 \\
\hline $\begin{array}{l}\text { Phoenicopteri- } \\
\text { formes }\end{array}$ & Phoenicopteridae & 3 & 0 & 0 & Piciformes & Picidae & 11 & 3 & 27 \\
\hline Phaethontiformes & Phaethontidae & 1 & 0 & 0 & Falconiformes & Falconidae & 12 & 3 & 25 \\
\hline Columbiformes & Columbidae & 11 & 0 & 0 & Passeriformes & Oriolidae & 1 & 1 & 100 \\
\hline Pterocliformes & Pteroclidae & 7 & 0 & 0 & & Laniidae & 10 & 3 & 30 \\
\hline \multirow[t]{2}{*}{ Caprimulgiformes } & Caprimulgidae & 4 & 0 & 0 & & Corvidae & 13 & 6 & 46 \\
\hline & Apodidae & 7 & 2 & 29 & & Paridae & 9 & 5 & 56 \\
\hline Cuculiformes & Cuculidae & 4 & 2 & 50 & & Remizidae & 1 & 0 & 0 \\
\hline \multirow[t]{3}{*}{ Gruiformes } & Rallidae & 9 & 2 & 22 & & Alaudidae & 25 & 5 & 20 \\
\hline & Gruidae & 2 & 0 & 0 & & Panuridae & 1 & 0 & 0 \\
\hline & Otididae & 5 & 0 & 0 & & Cisticolidae & 3 & 0 & 0 \\
\hline Gaviiformes & Gaviidae & 4 & 0 & 0 & & Acrocephalidae & 17 & 6 & 35 \\
\hline \multirow[t]{2}{*}{ Procellariiformes } & Hydrobatidae & 6 & 0 & 0 & & Locustellidae & 5 & 0 & 0 \\
\hline & Procellariidae & 12 & 0 & 0 & & Hirundinidae & 7 & 1 & 14 \\
\hline Ciconiiformes & Ciconiidae & 2 & 0 & 0 & & Pycnonotidae & 3 & 0 & 0 \\
\hline \multirow[t]{3}{*}{ Pelecaniformes } & Threskiornithidae & 4 & 0 & 0 & & Phylloscopidae & 9 & 4 & 44 \\
\hline & Ardeidae & 12 & 4 & 33 & & Scotocercidae & 2 & 1 & 50 \\
\hline & Pelecanidae & 2 & 0 & 0 & & Aegithalidae & 1 & 0 & 0 \\
\hline \multirow[t]{4}{*}{ Suliformes } & Fregatidae & 1 & 0 & 0 & & Sylviidae & 17 & 7 & 41 \\
\hline & Sulidae & 2 & 0 & 0 & & Leiotrichidae & 4 & 0 & 0 \\
\hline & $\begin{array}{l}\text { Phalacrocoraci- } \\
\text { dae }\end{array}$ & 5 & 0 & 0 & & Certhiidae & 2 & 0 & 0 \\
\hline & Anhingidae & 1 & 0 & 0 & & Sittidae & 7 & 1 & 14 \\
\hline \multirow[t]{12}{*}{ Charadriiformes } & Burhinidae & 2 & 0 & 0 & & Troglodytidae & 1 & 1 & 100 \\
\hline & Haematopodidae & 1 & 0 & 0 & & Cinclidae & 1 & 0 & 0 \\
\hline & Recurvirostridae & 2 & 0 & 0 & & Sturnidae & 5 & 2 & 40 \\
\hline & Charadriidae & 20 & 1 & 5 & & Turdidae & 7 & 2 & 29 \\
\hline & Rostratulidae & 1 & 0 & 0 & & Muscicapidae & 39 & 7 & 18 \\
\hline & Scolopacidae & 22 & 0 & 0 & & Regulidae & 3 & 1 & 33 \\
\hline & Turnicidae & 1 & 0 & 0 & & Hypocoliidae & 1 & 1 & 100 \\
\hline & Dromadidae & 1 & 0 & 0 & & Bombycillidae & 1 & 0 & 0 \\
\hline & Glareolidae & 4 & 0 & 0 & & Nectariniidae & 3 & 0 & 0 \\
\hline & Laridae & 50 & 6 & 12 & & Prunellidae & 5 & 0 & 0 \\
\hline & Stercorariidae & 4 & 0 & 0 & & Passeridae & 11 & 5 & 45 \\
\hline & Alcidae & 6 & 0 & 0 & & Motacillidae & 15 & 9 & 60 \\
\hline \multirow[t]{2}{*}{ Strigiformes } & Tytonidae & 1 & 0 & 0 & & Fringillidae & 29 & 0 & 0 \\
\hline & Strigidae & 16 & 3 & 19 & & Emberizidae & 19 & 5 & 26 \\
\hline \multirow[t]{2}{*}{ Accipitriformes } & Pandionidae & 1 & 0 & 0 & & & & & \\
\hline & Accipitridae & 33 & 1 & 3 & Total & & 651 & 106 & 16 \\
\hline
\end{tabular}




\section{6 species \\ (9 non-PAL species)
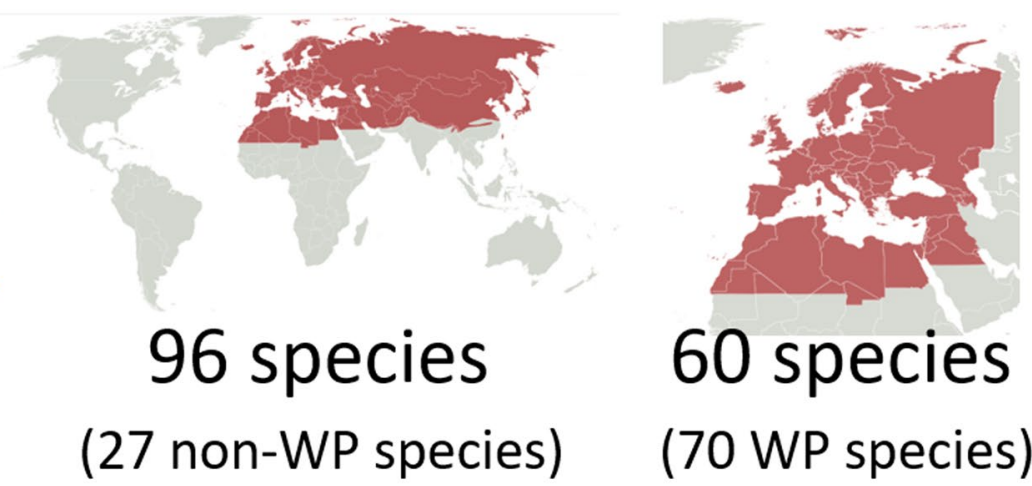 \\ (70 WP species)}

Fig. 1 Number of Western Palearctic bird species found to eat cicadas in studies carried out around the World, in the Palearctic and in the Western Palearctic. In brackets: number of Western Palearctic bird species estimated to eat cicadas around the World (outside the Palearctic), in the Palearctic (outside the Western Palearctic) and in the Western Palearctic (see text for calculation method). Maps under license CC BY-SA 3.0 (By carol_ecozones and Image:BlankMap-World6, compact.svg by User:Lokal_Profil., CC BY-SA 3.0, https://commons.wikimedia.org/w/index.php?curid $=3698005)$

The number of cicadas found eaten by birds, when recorded, varied between bird species. Some of the most relevant examples found in the CBWP from studies conducted in the WP are: 88 individual cicadas found in 3 pellets from the Common Swift (Apus apus); 16 individuals from 17 pellets in the Alpine Swift (Tachymarptis melba); first cited main prey in the Common Gull-billed Tern (Gelochelidon nilotica) from 25 stomachs analysed; $8 \%$ of 129 items collected at nest in the European Roller (Coracias garrulus); $5.2 \%$ of 96 items delivered to nestlings 4-8 days old in the Olive-backed Pipit (Anthus hodgsoni); $12 \%$ by number in 16 stomachs of Eurasian the Golden Oriole (Oriolus oriolus); 70\% of 102 insects from nestling neck-collar samples in the Pale Sparrow (Carpospiza brachydactyla); $28 \%$ by number from 138 invertebrate species found in 20 stomachs of the Lesser Whitethroat (Sylvia curruca); and $18 \%$ of invertebrates by number in 10 stomachs of the Sardinian Warbler ( Sylvia melanocephala). In studies other than the CBWP, the occurrence of cicadas in 119 of 215 pellets of the Eleonora's Falcon (Falco eleonorae) breeding in Crete, where four out of eight stomachs were also found full of cicadas (Ristow 2004), is worthy of note. Moreover, 18 individuals were collected from 66 stomachs of the Eurasian Jackdaw (Corvus monedula) (Hadjisterkotis 2003). In other parts of the Palearctic, the number of cicadas in relation to total number of prey reached 23\% (in 120 collar samples from the Rock Pipit Anthus petrosus).

Ten bird species were found to eat cicada nymphs: six passerines, the Little Owl (Athene noctua) (Vezinet 2003), the Little (Egretta garzetta) and the Great White Egrets (Ardea alba) (Privileggi et al. 2009), and the Common Moorhen (Gallinula chloropus) (Sazima 2009), although the latter in Brazil. Studies in the WP seldom identified Cicadidae consumed to finer taxonomic levels. However, a strong predator-prey relationship was found between the Eurasian Jay (Garrulus glandarius) and Cicada orni (Patterson et al. 1997). In several internet images, Cicada spp. was determined (by distribution C. orni, or C. orni/C. barbara), as also was Lyristes plebejus, both consumed by different bird species. Near the south-eastern limits of the WP, Platypleura arabica constituted a preferred prey for European (Merops apiaster) and Blue-cheeked Bee-eaters (M. persicus) (Kossenko and Fry 1998).

\section{Discussion}

This study illustrates the importance of considering old references and sources not included in the Science Citation Index to get missing information about biodiversity. For disciplines with a long tradition, such as food regime studies, it would be common sense not to restrict bibliographic searches to the latest decades. Our results show that, when available, cicadas are predated on by many terrestrial birds of the WP, including cuckoos, owls, beeeaters, woodpeckers, falcons, reed-warblers, larks, crows and jays, buntings, shrikes, pipits and wagtails, flycatchers and chats, tits, sparrows, leaf-warblers, starlings, warblers and thrushes. Cicadas are indeed commonly found in the diet of insectivorous birds such as bee-eaters, Sylvia warblers and pipits during the breeding season (Turrian and Jenni 1991; Kossenko and Fry 1998), but can also make up as much as $70 \%$ of food items delivered to nestlings in the mostly granivorous Pale Sparrow (Cramp et al. 1998). Even for medium-sized raptors, like the Peregrine Falcon, these insects can constitute a main prey (Ellis et al. 2007). More surprisingly, cicadas are important food for several species of terns and herons that can 

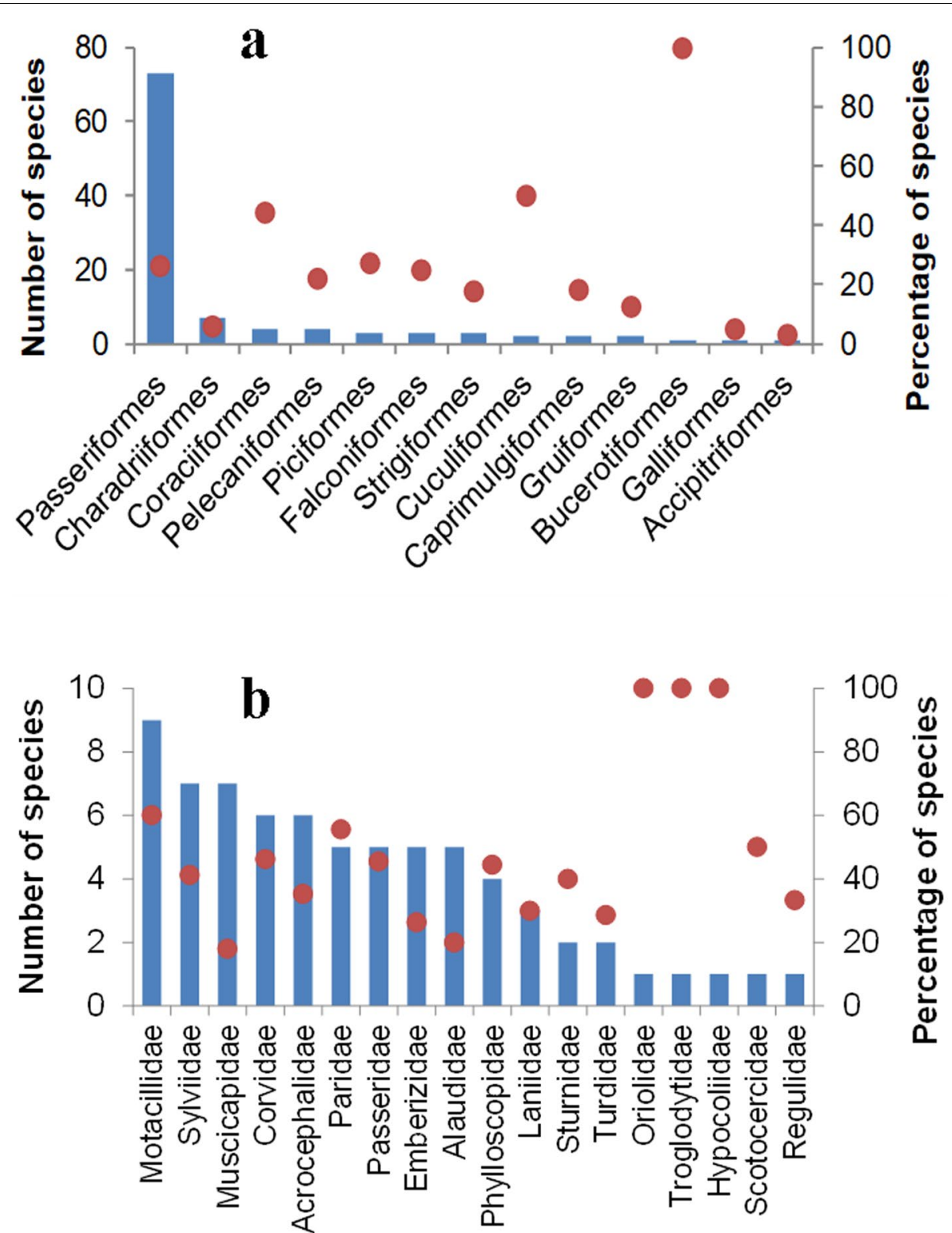

Fig. 2 Western Palearctic bird species found to eat cicadas per order (a), and per family within passerines (b). Bars show number of species; points percentage of species of the taxonomic group found to eat cicadas. Orders and families with no cicadas in diet are not shown

feed on nymphs emerging near the shore of ponds and wetlands, or in grasslands (Privileggi et al. 2009). Some Laridae, like the Mediterranean Gull and the Gull-billed Tern, can feed young mostly with insects (Goutner 1994; Bertolero and Rivaes 2015). Cicadas can also be a preferred prey, hunted on the wing and in the ground (e.g. by the Roseate Tern Sterna dougallii, foraging near nesting colonies; Forbusch 1924).

An estimated 34\% of WP bird species are only known to consume Cicadidae from studies carried out outside the WP, including an estimated 9\% outside the Palearctic.
These are bird species with cosmopolitan distribution or very large range, whose diet has been studied in other biogeographic realms. It is likely that they also eat cicadas in the WP whenever they are available. In the Afrotropical and Oriental realms, local abundance of cicadas could be relevant for the survival of WP overwintering birds. However, studies on diets of terrestrial birds in these wintering grounds, with the exception of some falcons and raptors (e.g. Verma 2005; Kopij 2007) are scarce. When available, the coarse taxonomic classification of prey items does not allow verifying the occurrence of 


\section{CBWP}

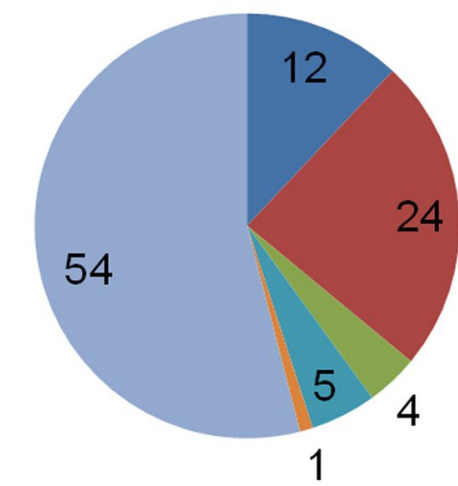

\section{Other}

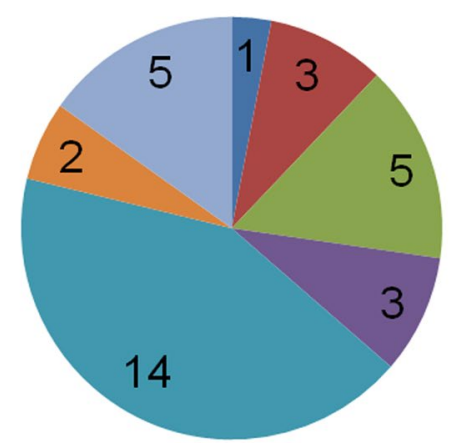

Fig. 3 Number of bird species studied by different diet methods (neck collars, stomach analysis, pellets and regurgitations, droppings, observation and photography, and nest remains) found in the Cramp's Birds of the Western Palearctic on CD-Rom (CBWP; studies mostly 1920-1989) and in other sources (Other; mostly 1990-2019). A species contributes to more than one category if it has been studied by different methods

cicadas in samples. On the other hand, WP bird species that overwinter in the south of the region (including the Mediterranean Basin) do not encounter cicadas, that are belowground and emerge at the end of the spring and in summer.

It is still soon to draw solid conclusions about the relative importance of cicadas as prey for birds in the WP. The diet of many bird species has not been studied in detail and, when it has, studies have seldom offered a broad geographical and temporal scope (Cramp et al. 1998). The results obtained are therefore biased towards those species that have been more intensively studied. Moreover, many studies lack proper quantification of prey items based on large samples. Nevertheless, the predominance of studies conducted in Mediterranean and Middle East countries, finding cicadas in the diet, matches the north-south gradient in species richness and also cicada abundance in landscapes. An additional, although probably minor problem, stems from studies in which Cicadidae in samples have been incorrectly cited and which could have gone undetected despite the search filters. Most gaps in diet studies have not been filled in recent years. However, a change in methods commonly used towards observational studies and non-invasive approaches analysing the contents of pellets or droppings (Fig. 3) has been taking place. Moreover, promising molecular techniques are being developed, like DNA sequencing-based diet analyses (Alberdi et al. 2019). The increasing affordability of molecular sequencing techniques may help expand these studies in the future, with a focus on threatened species, underrepresented in studies so far. In sum, the figure of $16 \%$ of WP bird species consuming cicadas is more an expression of our current knowledge of bird diets than an estimate of the real proportion of species preying on Cicadidae.

Logically, the follow-up question is what new species can we expect to find eating cicadas? A possible reasoning considers predators-prey body size relationships (Barnes et al. 2010). Fifteen bird species are either known to eat periodical cicadas or to be demographically affected by cicada emergences in the hardwood forests of the eastern United States (Koenig and Liebhold 2005). Their body masses range from the $17 \mathrm{~g}$ of the Red-eyed Vireo (Vireo olivaceus) to the $453 \mathrm{~g}$ of the American Crow (Corvus brachyrhynchos) (Birds of North America 2019). In turn, the body mass of Magicicada spp. (3 species of 13-year cicadas) oscillates between $0.15 \mathrm{~g}$ for males and $0.21 \mathrm{~g}$ for females (Rowell and Grammer 2019). The weight of birds known to eat cicadas in the WP ranges from $5.5 \mathrm{~g}$ in the Goldcrest (Regulus regulus) to more than $1000 \mathrm{~g}$ in the Raven (Corvus corax), the Great White Egret, the Grey Heron (Ardea cinerea) and the Peregrine falcon (Falco peregrinus). The largest cicada in the WP, Lyristes plebejus, is $1.8 \mathrm{~g}$ and the common forest species Cicada orni is $0.7 \mathrm{~g}$ (unpublished data). But species belonging to genera Cicadetta or Tettigettalna, among others, are much lighter and easier to seize and process by the small beaks of some insectivores. The consumption of cicadas by the Goldcrest shows that there is no body size limitation for birds to prey on Cicadidae species. It is therefore likely that most bird families and species in the WP can potentially eat cicadas. The potential list should exclude marine and wetland birds with specialized aquatic diets, nectarivorous sunbirds and possibly large raptors and vultures. Regarding habitats, cicadas are captured by birds from marshes and grasslands, to shrublands and forests. This predation is likely more intense in woodlands, where higher species richness and abundance are usually found (Puissant 2006).

Western Palearctic cicadas are difficult to find when hidden in vegetation or still against their background 
of bark or twigs. They also have good sight and are relatively quick flyers over short distances. Adults are unlikely to be easily captured in dense vegetation. However, preying on flightless nymphs can be much easier. Predation takes place mostly when they emerge from belowground and are walking to reach a support to moult. Although this only takes a few minutes, emerged nymphs can support high predation rates (of 24\%) in Mediterranean forests, mostly by birds (Patterson et al. 1997). Additional predation can happen while moulting and drying wings on substrates close to the ground. While walking or moulting, nymphs are mainly predated on by ground-foraging birds (Sazima 2009). It is interesting to note that many cicada species emerge before dawn, probably to avoid most predators. Owls can then become their main avian predators (Vezinet 2003).

Recent reviews have quantified the global contribution of insectivorous birds to the ecosystem service of regulating insect populations (Nyffeler et al. 2018). Since both insect populations, and birds species that feed on insects are threatened and continue declining worldwide (Sánchez-Bayo and Wyckhuys 2019; Sekercioğlu et al. 2004), studies of bird species diets are now of foremost relevance. Large insects in particular have suffered abundance declines (Shortall et al. 2009) and cicadas can be a temporarily abundant alternative prey. Cicadas are found aboveground in late spring and summer, coinciding with chick rearing and the postfledging period, in the WP. The juvenile survival of species selecting cicada as main prey, like the Eurasian Jay, may therefore increase in response to a locally high cicada density (Patterson et al. 1991).

\section{Conclusions}

Birds contribute to the bottom-down regulation of cicada populations (Speight et al. 2008). Simultaneously, cicadas are a preferred prey for Western Palearctic birds, which can shape their foraging behaviour and movements (Rolando 1998). However, most Cicadidae populations appear aggregated in space and in time (Sueur and Puissant 2002; Puissant and Sueur 2010). The main relevance of cicada availability for bird populations is likely to enhance the breeding success and post-fledging survival of their avian predators at local scales. Nevertheless, more studies are needed on the relative importance of cicadas as prey for birds in the Western Palearctic. I suggest using non-invasive diet studies based on pellets and droppings, conducting finer taxonomic classification of prey items, and prioritizing declining bird species to help in conservation actions.

\section{Supplementary information}

Supplementary information accompanies this paper at https://doi. org/10.1186/s40657-020-00200-1.

Additional file 1: Appendix 1. The database of cicada-eating birds occurring in the Western Palearctic.

\section{Acknowledgements}

Thanks are due to Roger Puig-Gironès for his help with data search, to Gabriel Gargallo for comments on an earlier draft and to Diane Harper who revised the English.

\section{Funding}

The author was supported by grant CGL2014-54094-R from the Spanish Ministry of Economy and Competitiveness.

\section{Availability of data and materials}

The main dataset of the study is provided in Additional file 1: Appendix 1.

Ethics approval and consent to participate

Not applicable.

Consent for publication

Not applicable.

\section{Competing interests}

The author declares that he has no competing interests.

Received: 19 March 2020 Accepted: 6 May 2020

Published online: 12 May 2020

\section{References}

Alberdi A, Aizpurua O, Bohmann K, Gopalakrishnan S, Lynggaard C, Nielsen M, et al. Promises and pitfalls of using high-throughput sequencing for diet analysis. Mol Ecol Resour. 2019;19:327-48.

Barnes C, Maxwell D, Reuman DC, Jennings S. Global patterns in predator-prey size relationships reveal size dependency of trophic transfer efficiency. Ecology. 2010;91:222-32.

Bertolero A, Rivaes S. Synthèse des connaissances sur le régime alimentaire de la Sterne Hansel (Gelochelidon nilotica) en région Méditerranéenne. Rev Ecol Terre Vie. 2015;70:83-90.

Birds of North America. List of North American Birds. 2019. https://www.birds -of-north-america.net/list-of-north-american-birds.html. Accessed $15 \mathrm{Mar}$ 2019.

Boulard M, Mondon B. Vies et mémoires de cigales. Barbentane, France: Editions de l'Equinoxe; 1995.

Capinera JL. Insects and wildlife: arthropods and their relationships with wild vertebrate animals. Chichester: Wiley-Blackwell; 2010.

Cramp S, Snow DW, Perrins CM (eds) The complete birds of the Western Paleartic. CD-ROM v.1.0. Oxford: Oxford University Press; 1998.

Dean WRJ. Alpine swifts opportunistically feeding on cicadas. Ostrich. 1993;64:42-3.

Ellis DH, LaRue CT, Fackler JK, Nelson RW. Insects predominate in peregrine falcon predation attempts in Arizona. Western Birds. 2007;38:261-7.

Enciclopedia of Life. Cicadidae. 2019. https://eol.org/pages/2645413/articles. Accessed 14 Mar 2019.

Farina A, Pieretti N, Piccioli L. The soundscape methodology for long-term bird monitoring: a Mediterranean Europe case-study. Ecol Inform. 2011;6:354-63.

Forbush EH. Gulls and terns feeding on the seventeen-year cicada. Auk. 1924;41:468-70.

Gogala M. Songs of European singing cicadas. 2019. http://www.cicadasong .eu/ Accessed 30 May 2019.

Goutner V. The diet of Mediterranean Gull (Larus melanocephalus) chicks at fledging. J Ornithol. 1994;135:193-201. 
Hadjisterkotis E. The effect of corvid shooting on the populations of owls, kestrels and cuckoos in Cyprus, with notes on corvid diet. Z Jagdwiss. 2003:49:50-60.

HBW and BirdLife International. Handbook of the birds of the world and BirdLife International digital checklist of the birds of the world. Version 3. 2018. http://datazone.birdlife.org/userfiles/file/Species/Taxonomy/HBWBirdLife_Checklist_v3_Nov18.zip. Accessed 5 April 2019.

Itamies J, Putaala A, Pirinen M, Hissa R. The food composition of grey partridge chicks Perdix perdix in central Finland. Ornis Fenn. 1996;73:27-34.

Karban R. Increased reproductive success at high densities and predator satiation for periodical cicadas. Ecology. 1982;63:321-8.

Koenig WD, Liebhold AM. Effects of periodical cicada emergences on abundance and synchrony of avian populations. Ecology. 2005;86:1873-82.

Koenig WD, Liebhold AM. Avian predation pressure as a potential driver of periodical cicada cycle length. Am Nat. 2013;181:145-9.

Kopij G. Seasonal and annual dietary changes in Lesser Kestrels Falco naumanni wintering in Lesotho. Ostrich. 2007;78:615-9.

Kossenko SM, Fry CH. Competition and coexistence of the European Bee-eater Merops apiaster and the Blue-cheeked Bee-eater Merops persicus in Asia. Ibis. 1998;140:2-13.

Lovette IJ, Fitzpatrick JW, editors. Handbook of bird biology. Oxford: The Cornell Lab of Ornithology and Wiley; 2016.

Marshall DC, Moulds M, Hill KBR, Price BW, Wade EJ, Owen CL, et al. A molecular phylogeny of the cicadas (Hemiptera: Cicadidae) with a review of tribe and subfamily classification. Zootaxa. 2018;4424:1-64.

Nyffeler M, Şekercioğlu ÇH, Whelan CJ. Insectivorous birds consume an estimated 400-500 million tons of prey annually. Sci Nat. 2018;105:47.

Patterson IJ, Cavallini P, Rolando A. Density, range size and diet of the European Jay Garrulus glandarius in the Maremma Natural Park, Tuscany, Italy, in summer and autumn. Ornis Scand. 1991;22:79-87.

Patterson IJ, Massei G, Genov P. The density of cicadas Cicada orni in Mediterranean coastal habitats. Ital J Zool. 1997;64:141-6.

Pons P. Delayed effects of fire and logging on cicada nymph abundance. J Insect Conserv. 2015;19:601-6.

Privileggi N, Colla A, Vicario G. L'alimentazione della garzetta Egretta garzetta e dell'airone bianco maggiore Ardea alba nella Valle Canal Novo di Marano Lagunare (Udine). Avocetta. 2009;33:57-86.

Puissant S. Contribution a la connaissance des cigales de France: geonemie et écologie des populations (Hemiptera, Cicadidae). Bédeilhac et Aynat: Ascete; 2006

Puissant S, Sueur F. A hotspot for Mediterranean cicadas (Insecta: Hemiptera: (icadidae): new genera, species and songs from southern Spain. Sistem Biodivers. 2010;8:555-74.
Ristow D. On the insect diet of Eleonora's Falcon Falco eleonorae and its importance for coloniality. In: Chancellor RD, Meyburg B-U, editors. Raptors worldwide: Proceedings of the VI World Conference on birds of prey and owls. World Working Group on Birds of Prey and Owls and MME/BirdLife Hungary, Budapest; 2004; pp. 705-12.

Rolando A. Factors affecting movements and home ranges in the jay (Garrulus glandarius). J Zool. 1998;246:249-57.

Rowell G, Grammer R. Cicada data. 2019. http:/www.randomservices.org/ random/data/Cicada.html. Accessed 15 Mar 2019.

Sanborn AF, Phillips PK, Heath JE, Heath MS. Comparative thermal adaptation in cicadas (Hemiptera: Cicadidae) inhabiting Mediterranean ecosystems. J Therm Biol. 2011;36:150-5.

Sánchez-Bayo F, Wyckhuys KAG. Worldwide decline of the entomofauna: a review of its drivers. Biol Conserv. 2019:232:8-27.

Sazima I. Insect cornucopia: various bird types prey on the season's first giant cicadas in an urban park in southeastern Brazil. Biota Neotrop. 2009;9:259-62

Sekercioğlu CH, Daily GC, Ehrlich PR. Ecosystem consequences of bird declines. Proc Natl Acad Sci USA. 2004;101:18042-7.

Senter P. Voices of the past: a review of Paleozoic and Mesozoic animal sounds. Hist Biol. 2008;20:255-87.

Shortall CR, Moore A, Smith E, Hall MJ, Woiwod IP, Harington R. Long-term changes in the abundance of flying insects. Insect Conserv Divers. 2009;2:251-60

Simoes PC, Sanborn A, Quartau JA. Two new species of Cicadatra (Hemiptera: Cicadoidea) from Greece. Entomol Sci. 2013;16:83-90.

Speight MR, Hunter MD, Watt AD. Ecology of insects: concepts and applications. 2nd ed. Chichester: August Wiley-Blackwell; 2008.

Sueur J, Puissant S. Spatial and ecological isolation in cicadas: first data from Tibicina (Hemiptera: Cicadoidea) in France. Eur J Entomol. 2002;99:477-84.

Tokue K, Ford HA. The influence of patterns of food abundance on the breeding seasons and clutch-sizes of red wattlebirds and noisy friarbirds. Emu. 2007;107:151-5.

Torno MM. Diet analysis of two species of bee-eaters (Aves: Meropidae) based on regurgitated pellets. Sylvatrop. 2005;15:103-12.

Turrian $F$, Jenni $L$. Etude de trois especes de fauvettes en periode de migration postnuptiale a Verbois, Geneve: evolution de la masse, offre en nourriture et regime alimentaire. Alauda. 1991;59:73-88.

Verma A. Winter ecology of harriers roosting at Akola, Maharashtra, India. Zoos' Print J. 2005;20:1943-7

Vezinet P. La chevêche et les cigales. Insectes. 2003;131:13-4.
Ready to submit your research? Choose BMC and benefit from:

- fast, convenient online submission

- thorough peer review by experienced researchers in your field

- rapid publication on acceptance

- support for research data, including large and complex data types

- gold Open Access which fosters wider collaboration and increased citations

- maximum visibility for your research: over 100M website views per year

At $\mathrm{BMC}$, research is always in progress.

Learn more biomedcentral.com/submissions 